\title{
DESAIN DAN IMPLEMENTASI PERINGATAN DINI BANJIR MENGGUNAKAN DATA MINING DENGAN WIRELESS SENSOR NETWORK
}

\author{
Roni Putra ${ }^{1 *}$, Zaini $^{2}$, Era Madona ${ }^{3}$ dan Anggara Nasution ${ }^{4}$ \\ ${ }^{1,2}$ Jurusan Teknik Elektro, Fakultas Teknik, Univertsitas Andalas \\ ${ }^{3,4}$ Teknik Elektro Politeknik Negeri Padang \\ *Corresponding author, e-mail :rn.putra@gmail.com
}

\begin{abstract}
Abstrak - Tulisan ini bertujuan untuk mengembangkan sistem peringatan dini banjir dan informasi cuaca. Hal ini dilatarbelakangi oleh keadaan Indonesia yang mempunyai dan mengalami perubahan musim yang cukup drastis. Perubahan musim dan kondisi cuaca yang tidak stabil dapat memicu terjadinya bencana seperti banjir yang disebabkan oleh curah hujan yang tinggi sebagaimana yang terjadi di Kota Padang. Daerah Batu Busuk merupakan salah satu area rawan banjir dan galodo akan tetapi tidak terdapat informasi tentang keadaan cuaca. Penelitian ini bertujuan memberikan informasi cuaca dan prediksi akan potensi banjir dengan variable curah hujan, suhu, kelembaban, arah angin dan kecepatan angin yang dapat diakses secara realtime dan up to date dimanapun dan kapanpun melalui webpage online. Untuk menentukan prediksi potensi banjir maka digunakan data mining dengan metoda Alogritma C4.5 yang menghasilkan pohon keputusan. Penelitian ini juga menggunakan XBee S2PRO untuk pengirim dan penerima dengan to pology mesh yang terdiri dari komponen sensor curah hujan, SHT11, arah angin, kecepatan angin serta arduino. Penyimpanan data dan pengolahan informasi menggunakan Raspberry Pi sebagai komputer mini server. Hasil pengukuran sensor SHT11 mempunyai kesalahan rata-rata pada suhu $2,09 \%$, kelembaban relative 0,59\%, kecepatan angin 3,87\% dan arah angin $0 \%$ serta curah hujan $6,32 \%$ dari pengukuran alat ukur sebenarnya. Pengujian selama empat hari memiliki persamaan kondisi cuaca antara alat EWS dengan keadaan di Batu Busuk, dimana pada tanggal 22 Maret 2016 pukul 05:35 WIB sistem informasi Early Warning System (EWS) mengeluarkan warning system akan potensi banjir dan pada saat pagi hari aliran Batu Busuk mengalami banjir.
\end{abstract}

Kata Kunci : Data mining, Algoritma C4.5, XBee S2Pro, Raspberry Pi.

\begin{abstract}
The aim of this article is develop a warning system of early flood and weather information. This research was inspired by not stabilize weather condition of Indonesian. It will cause disaster such as flood because of the hight rainfall, as happened in Padang. Batu Busuk is one of the flood-prone area and galodo but there is no information about the weather, rainfall, humidity, temperature and wind speed and direction. The aim of this study is giving weather data and forecast information of the potential flood with variable rainfall, temperature, humidity, wind direction and wind speed which can be access realtime and up to date wherever and whenever via the webpage online. To determine the potential for flooding prediction by used data mining with a method of Alogritma C4.5 its can be result of decision tree. In this study using XBee S2PRO for sender and recipient with mesh topology which consists of a rainfall sensor components, SHT11, wind speed and direction as well as the arduino. Data storage and processing of information using the Raspberry Pi as a mini computer server. The result of sensor SHT11 measurement is a little difference with really measurement such as: $2.09 \%$ temperature, relative humidity of $0.59 \%, 3.87 \%$ wind speed, wind direction and precipitation $0 \% 6.32 \%$. Meanwhile, the results of experiment in Batu Busuk proved the same weather conditions between EWS tool with the situation in Batu Busuk during the four day, where on March 22, 2016 at 5:35 PM information system Early Warning System (EWS) issued a warning system would be the potential for flood and after it be floded Batu Busuk.
\end{abstract}

Keywords : Data mining, Algorithm C4.5, XBee S2Pro, Raspberry Pi.

Copyright $\odot 2016$ JNTE. All rights reserved

\section{PENDAhuluan}

Indonesia [1] merupakan Negara yang berada pada zona rawan bencana sehingga sering menimbulkan banyak korban jiwa dan harta benda. Batu Busuk merupakan salah satu area rawan banjir dan galodo akan tetapi tidak terdapat informasi tentang keadaan cuaca sehingga jika terjadi banjir dan galodo berefek besar terhadap daerah aliran sungai Batu Busuk ditambah adanya perbedaan cuaca antara Batu Busuk dengan sepanjang daerah aliran sungai. 
Dengan adanya perbedaan cuaca sulit daerah aliran sungai memperdiksi apakah cuaca di Batu Busuk sangat ekstrim yang berpotensi banjir atau tidak. Dengan demikian [2] penting bagi kita untuk memastikan resiko akibat bencana dengan melakukan prediksi yang efektif, deteksi, monitoring, peringatan dini dengan menggunakan sistem informasi.

Penduduk hanya bisa menganalisa secara visual dengan melihat dari jauh apakah adanya tanda-tanda hujan seperti adanya gumpalan awan hitam. Sulitnya memprediksi keadaan cuaca maka masyarakat daerah aliran sungai Batu Busuk tidak bisa mempersiapkan diri dan barang-barang untuk melakukan evakuasi jika akan terjadinya banjir dan galodo dimana dapat menimbulkan effek kerugian dari segi materi dan nyawa. Early Warning System (EWS) yang dibangun memiliki kemampuan memprediksi banjir dengan menggunakan data mining, data mining merupakan historis kejadian yang pernah terjadi sebelumnya, dimana data yang diambil dari BMKG, serta diolah dengan menggunakan metoda Algoritma C4.5 sehingga menghasilkan pohon keputusan apakah berpotensi banjir atau tidak. Sedangkan pengiriman data sendiri menggunakan wireless sensor network (WSN) serta sebuah mini komputer Raspberry Pi digunakan sebagai web server untuk pemprosesan dari EWS. Informasi data cuaca dan prediksi akan potensi banjir atau dapat diakses secara realtime dan up to date dimanapun dan kapanpun [3] karena bisa diakses melalui webpage secara online, apakah dengan tab, smartphone serta laptop dan PC. Berangkat dari paparan diatas peneliti merasa perlu untuk melakukan penelitian lebih lanjut mengenai hal tersebut.

\section{TINJAUAN PUSTAKA}

\subsection{Data Mining}

Data mining [4] adalah teknologi baru dan berhasil diterapkan pada banyak bidang, tujuan keseluruhan dari proses data mining adalah untuk mengekstrak informasi dari kumpulan data dan mengubahnya menjadi struktur yang dimengerti. Data mining terutama digunakan untuk klasifikasi model dan prediksi.

\subsection{Algoritma $\mathrm{C} 4.5$}

Algoritma data mining C4.5 merupakan salah satu algoritma yang digunakan untuk melakukan klasifikasi atau segmentasi atau pengelompokan dan bersifat prediktif. Dasar algoritma C4.5 [5] adalah pembentukan pohon keputusan (decision tree). Cabang-cabang pohon keputusan merupakan pertanyaan klasifikasi dan daun-daunnya merupakan kelaskelas atau segmensegmennya. Pemilihan atribut sebagai simpul, baik akar (root) atau simpul internal didasarkan pada nilai Gain tertinggi dari atribut-atribut yang ada. Perhitungan nilai Gain digunakan rumus seperti dibawah ini.

$$
\operatorname{Entropi}(S)=\sum_{j=1}^{j}-\operatorname{pj} \log _{2} \mathrm{pj}
$$

Dimana :

$$
\begin{aligned}
& \mathrm{S}: \text { Himpunan kasus } \\
& \mathrm{A}: \text { Atribut } \\
& \mathrm{N}: \text { Jumlah partisi atribut A } \\
& |\mathrm{Si}| \text { : Jumlah kasus pada partisi ke-i } \\
& |\mathrm{S}| \text { : Jumlah kasus dalam } \mathrm{S}
\end{aligned}
$$

Untuk menghitung nilai Entropy dapat dilihat pada rumus dibawah ini.

$$
\operatorname{Gain}(A)=\operatorname{Entropi}(\mathrm{S})-\sum_{k=1}^{k} \frac{\left|S_{i}\right|}{|S|} x \operatorname{Entropi}\left(S_{i}\right)
$$

\subsection{Raspberry $P i$}

Raspberry Pi [6] merupakan komputer mini yang memiliki ukuran kecil yaitu sebesar kartu ATM tetapi mampu menjalankan tugas yang sama dengan komputer PC. Tetapi di lapangan kebanyakan aplikasi web server tidak akan menangani sebegitu banyak permintaan sehingga bakal tidak akan memanfaatkan sepenuhnya potensi dari hardware yang dimilikinya. Dengan menggunakan Raspberry Pi sebagai server lebih efisien dari pada menggunakan PC Server yang dari segi harga sangat mahal.

\subsection{Zigbee}

ZigBee adalah protokol jaringan nirkabel yang ditargetkan untuk otomasi dan aplikasi remote control dengan teknologi data rate rendah [7], konsumsi daya rendah, dan harga murah. Protokol Zigbee dapat mendukung topologi jaringan star, tree dan mesh. Dengan menggunakan jaringan mesh [8] , jika salah satu 
titik tidak dapat beroperasi, maka titik-titik lainnya masih dapat berkomunikasi dengan baik, baik secara langsung maupun melewati satu atau beberapa titik perantara untuk dapat mencapai titik tujuan informasi.

XBee merupakan modul yang memungkinkan Arduino untuk berkomunikasi secara wireless menggunakan [9] protokol ZigBee. ZigBee beroperasi pada spesifikasi IEEE 802.15.4 radio fisik dan beroperasi pada band berlisensi termasuk $2.4 \mathrm{GHz}, 900 \mathrm{MHz}$ dan $868 \mathrm{MHz}$.

\subsection{Fuzzy Cluter Mean(FCM)}

Metode clustering [10] yang digunakan dalam penelitian ini adalah fuzzy c-means. Metode ini pertama kali dikenalkan oleh Jim Bezdek pada tahun 1981 (Kusumadewi, 2004). Fuzzy c-means adalah salah satu teknik pengklusteran data yang mana keberadaan tiap titik data dalam suatu cluster ditentukan oleh derajat keanggotan.

Cluster bertujuan dalam penentuan EWS (Early Warning System) dengan menggunakan metoda Algoritma C4.5. Keluaran dari FCM merupakan deretan pusat cluster dan beberapa derajat keanggotaan untuk tiap-tiap data.

Tabel 1. Pembagian Himpunan Fuzzy

\begin{tabular}{|c|c|c|}
\hline No & Variabel & Himpunan Fuzzy \\
\hline \multirow{2}{*}{1} & \multirow{3}{*}{ Suhu(C) } & Rendah \\
\cline { 3 - 3 } & & Sedang \\
\cline { 3 - 3 } 2 & \multirow{2}{*}{ Kelembaban(\%) } & Tinggi \\
\cline { 3 - 3 } & & Rendah \\
\cline { 3 - 3 } & & Sedang \\
\hline
\end{tabular}

\subsection{Pengkategorian Curah Hujan}

Curah hujan 1 milimeter artinya dalam luasan 1 meter persegi tertampung air hujan setinggi 1 milimeter atau 1 liter. Untuk intensitas hujan per jam, mengacu pada standar Internasional (WMO) dapat dilihat pada Tabel 2.

Tabel 2. Kategori Curah Hujan Perjam

\begin{tabular}{|c|c|c|}
\hline No & $\begin{array}{c}\text { Kategori } \\
\text { Hujan }\end{array}$ & $\begin{array}{c}\text { Intensitas } \\
\text { hujan/jam }\end{array}$ \\
\hline 1 & Ringan & $0.1-5.0 \mathrm{~mm}$ \\
\hline 2 & Sedang / Normal & $5.0-10 \mathrm{~mm}$ \\
\hline 3 & Sangat Lebat & $>20 \mathrm{~mm}$ \\
\hline
\end{tabular}

Kategori curah hujan digunakan untuk melihat kondisi terbaru di Batu Busuk, sehingga informasinya bisa di akses secara realtime. Sedangkan kategori hujan harian dapat dilihat pada Tabel 3.

Tabel 3. Kategori Hujan Perhari

\begin{tabular}{|c|c|c|}
\hline No & $\begin{array}{c}\text { Kategori } \\
\text { Hujan }\end{array}$ & $\begin{array}{c}\text { Intensitas } \\
\text { hujan/hari }\end{array}$ \\
\hline 1 & Ringan & $5-20 \mathrm{~mm}$ \\
\hline 2 & Sedang / Normal & $21-50 \mathrm{~mm}$ \\
\hline 3 & Sangat Lebat & $>51 \mathrm{~mm}$ \\
\hline
\end{tabular}

\section{METODOLOGI PENELITIAN}

\subsection{Perancangan Sistem}

Secara umum, keseluruhan proses bekerjanya sistem dapat dilihat pada Gambar 1 alat yang akan dibangun diletakkan di Batu Busuk.

Proses dari diagram blok pada Gambar 1 dapat dijelaskan bahwa diagram ini terdiri dari 3 bagian pokok yaitu :

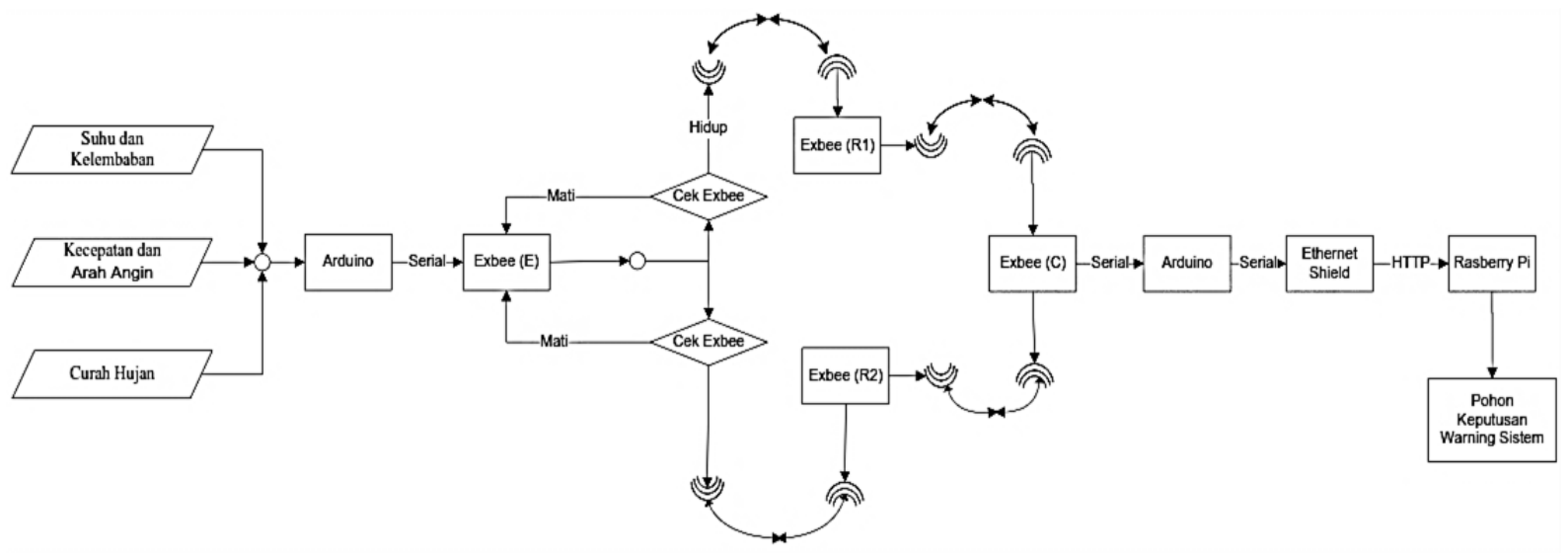

Gambar 1. Block Diagram Sistem 
1. Transmitter

Pada bagian transmitter ini memiliki beberapa sensor, diantaranya sensor curah hujan, kelembaban dan suhu serta kecepatan dan arah angin. Sensor-sensor itu akan diolah dengan mengunakan microcontroller mega2560 yang akan ditampilkan dalam bentuk serial, dimana data serial itu akan dikirim menggunakan wireless sensor network ke receiver.

\section{Router}

Setelah data dikirim dari transmitter akan diteruskan ke receiver melalui router, dikarenakan jarak antara transmitter dan receiver sangat jauh. Dalam proses perutean data, router bersifat melanjutkan transmisi paket data menuju alamat tujuan dalam jaringan. Fungsi ini membuat router harus selalu aktif dan membutuhkan daya lebih dalam operasinya. Dibagian ini terdapat 2 router, dimana dengan adanya 2 router ini berfungsi untuk membuat jalur backup jika salah satu router mati atau tidak berfungsi, sehingga pengiriman data tidak terputus.

\section{Receiver}

Pada bagian ini data yang telah dikirim transmitter melalui router akan diterima oleh receiver melalui wireless sensor network dalam bentuk data serial. Pada receiver sendiri terdiri dari arduino, Ethernet shield, Xbee, RTC dan modem router. Data yang telah diterima melalui XBee, akan dikirim kembali ke raspberry pi yang berfungsi sebagai server, pengiriman itu sendiri menggunakan Ethernet shield, untuk itu membutuhkan modem internet router. Data yang dikirim akan ditambahkan tanggal dan jam pengiriman oleh rangkaian RTC. Sehingga kita dapat membandingkan berapa delay data saat diBatu Busuk sampai ke server.

\section{Raspberry Pi}

Setelah data semua di kirim dari Batu Busuk melalui beberapa tahapan yang dilalui, data akan disimpan ke raspberry pi yang berfungsi sebagai server untuk penyimpanan data sensor ke mysql, selain itu raspberry pi juga memiliki tugas sebagai web server untuk menampilkan EWS dalam bentuk web page, sehingga informasi dari Batu Busuk dapat di akses.

\subsection{Perancangan Hardware}

Perancangan hardware dibagi atas tiga kelompok yaitu, perancangan transmitter, router dan receiver. Berikut ini proses perancangan hardware:

\section{Transmitter}

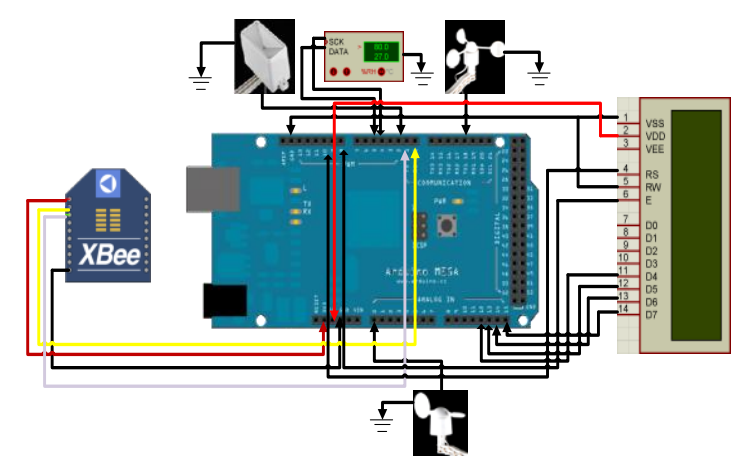

Gambar 2. Perancangan Hardware Transmitter

2. Router

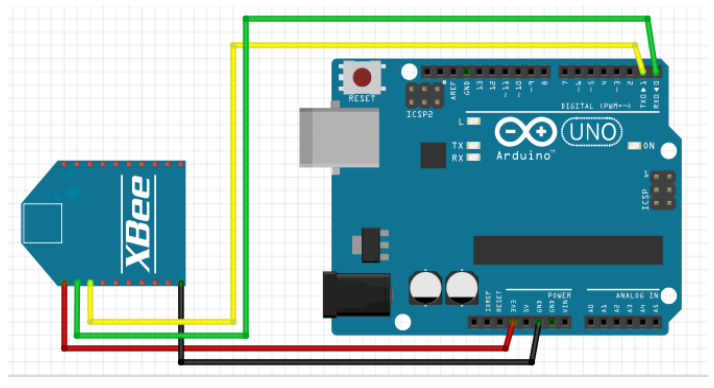

Gambar 3. Perancangan Router

3. Receiver

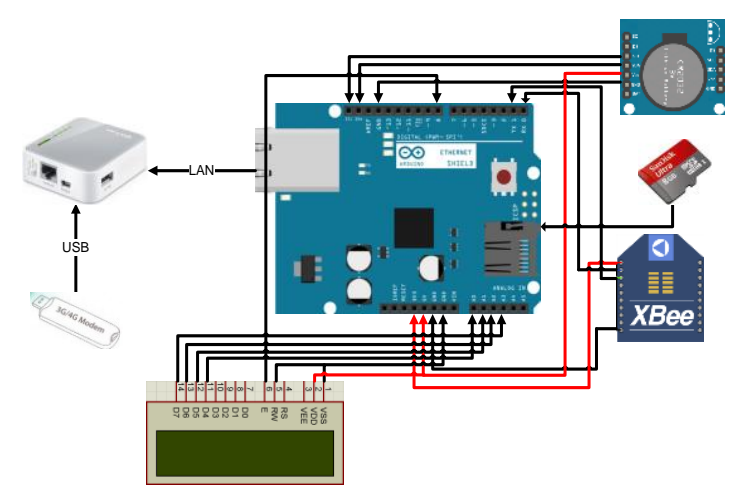

Gambar 4. Perancangan Hardware Reciever

\subsection{Perancangan Software}

Untuk peracangan Software memiliki beberapa tahapan yaitu:

1. Instalasi OS

2. Instalasi Web Server

3. Instalasi Database Server 
Tabel 4. Stuktur Databases

\begin{tabular}{|c|c|c|c|}
\hline No & Field & Type & Keterangan \\
\hline 1 & Id & $\operatorname{int}(11)$ & \\
\hline 2 & id_wil & $\operatorname{int}(11)$ & Wilayah \\
\hline 3 & n_hjn & $\operatorname{int}(11)$ & $\begin{array}{c}\text { Nilai Curah } \\
\text { Hujan }\end{array}$ \\
\hline 4 & n_temp & double & Nilai Suhu \\
\hline 5 & n_hum & double & $\begin{array}{c}\text { Nilai } \\
\text { Kelembaban }\end{array}$ \\
\hline 6 & n_kec_angin & double & $\begin{array}{c}\text { Nilai Kecepatan } \\
\text { Angin }\end{array}$ \\
\hline 7 & n_arah_angin & double & Nilai Arah Agin \\
\hline 8 & tgl_xbe & date & $\begin{array}{c}\text { Tanggal Batu } \\
\text { Busuk }\end{array}$ \\
\hline
\end{tabular}

4. Aplikasi Web Page EWS menggunakan bahasa pemograman PHP

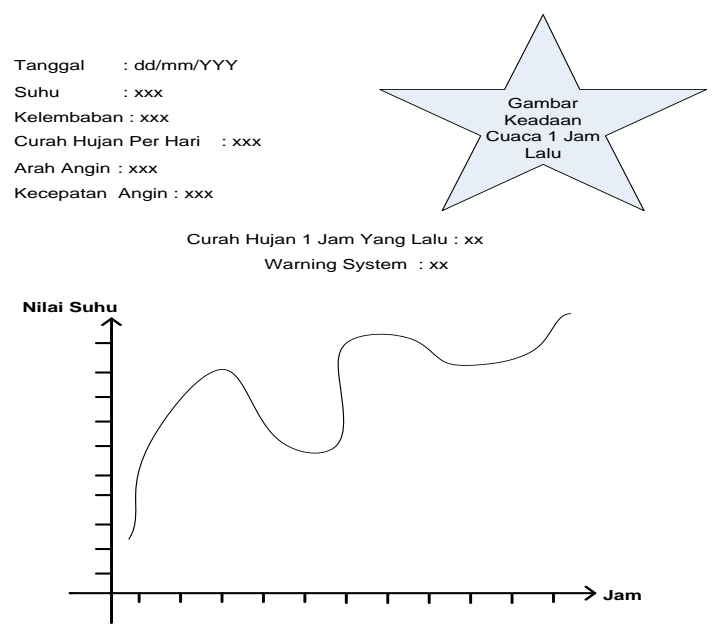

Gambar 5. Desain Web Page EWS

\section{HASIL DAN PEMBAHASAN}

\subsection{Hasil Pengukuran}

Dalam Pengukuran terdapat beberapa hal yang akan diuji diantaranya sensor SHT11, sensor Anemometer, sensor Wind Vane, sensor Rain Gauge. Untuk menghitung Error [11] dan $\%$ Error dapat dilihat pada rumus berikut:

Error=Nilai pembanding- nilai pengukuran

$$
\begin{gathered}
\% \text { Error }=\frac{\mid \text { Error } \mid}{\text { Nilai pembanding }} \times 100 \\
\text { Average \% Error }=\frac{\text { Total \% Error }}{\text { Jumlah Hasil Pengukuran }}
\end{gathered}
$$

\section{Sensor SHT11}

SHT11 adalah sebuah single chip sensor suhu dan kelembaban relatif dengan multi modul sensor yang outputnya telah dikalibrasi secara digital. Dibagian dalamnya terdapat kapasitas polimer sebagai elemen untuk sensor kelembaban relatif dan sebuah pita regangan

\begin{tabular}{|c|c|c|c|c|}
\hline \multirow{2}{*}{ NO } & $\begin{array}{l}\text { Suhu } \\
\text { HTC }\end{array}$ & Sensor & \multirow[b]{2}{*}{ Error } & \multirow{2}{*}{$\%$ Error } \\
\hline & $\left({ }^{\circ} \mathrm{C}\right)$ & $\begin{array}{c}\text { Suhu } \\
\left({ }^{\circ} \mathrm{C}\right)\end{array}$ & & \\
\hline 1 & 33,9 & 35 & $-1,1$ & 3,24 \\
\hline 2 & 34,1 & 35 & $-0,9$ & 2,64 \\
\hline 3 & 34,2 & 35 & $-0,8$ & 2,34 \\
\hline 4 & 34,2 & 35 & $-0,8$ & 2,34 \\
\hline 5 & 34,1 & 35 & $-0,9$ & 2,64 \\
\hline 6 & 33,9 & 35 & $-1,1$ & 3,24 \\
\hline 7 & 33,9 & 34 & $-0,1$ & 0,29 \\
\hline 8 & 33,8 & 34 & $-0,2$ & 0,59 \\
\hline 9 & 33,5 & 34 & $-0,5$ & 1,49 \\
\hline 10 & 33,3 & 34 & $-0,7$ & 2,10 \\
\hline & $\mathrm{Ne}$ & $10 \mathrm{EI}$ & & 2,09 \\
\hline
\end{tabular}
yang digunakan sebagai sensor temperature.

Tabel 5. Hasil pengujian suhu

2. Sensor Animometer

Sensor Animometer adalah sensor yang digunakan untuk mengukur kecepatan angin mengunakan prinsip magnetik switch.

Tabel 6. Hasil pengujian sensor Animometer

\begin{tabular}{|c|c|c|c|}
\hline $\begin{array}{c}\text { Kecepatan } \\
\text { Angin }\end{array}$ & Sample & Error & $\begin{array}{c}\% \\
\text { Error }\end{array}$ \\
\cline { 1 - 2 } Knots & Knot & & 3,00 \\
\hline 5 & 5,15 & $-0,15$ & 3,71 \\
\hline 7 & 6,67 & 0,33 & 4,71 \\
\hline 4 & 4,03 & $-0,03$ & 0,75 \\
\hline 3 & 3,12 & $-0,12$ & 4,00 \\
\hline 2 & 2,06 & $-0,06$ & 3,00 \\
\hline 8 & 8,37 & $-0,37$ & 4,62 \\
\hline 7 & 7,08 & $-0,08$ & 1,14 \\
\hline 3 & 3,27 & $-0,27$ & 9,00 \\
\hline 2 & 2,16 & $-0,16$ & 8,00 \\
\hline 4 & 3,98 & 0,02 & 0,50 \\
\hline \multicolumn{3}{|c|}{$\%$ Rata-rata Error } & 3,87 \\
\hline \multicolumn{3}{|l}{} \\
\hline
\end{tabular}

3. Sensor Wind Vane.

Sensor Wind Vane adalah sensor yang digunakan untuk mengukur arah angin, disaat magnet baling-baling sensor arah angin berputar, maka setiap derajatnya yang pada datasheet sensor memiliki 16 posisi akan menghasilkan tegangan yang berbeda-beda. Tegangan yang dihasilkan terjadi karena adanya keluaran dari pembagi tegangan yang diakibatkan oleh magnet yang menghubungkan magnetik switch. 
Tabel 7. Pengujian sensor arah angin

\begin{tabular}{|r|l|c|c|}
\hline \multicolumn{2}{|c|}{ Arah Angin } & Sample & Error \\
\cline { 1 - 2 } Volt & Arah Angin & $3,84 \mathrm{v}$ & 0 \\
\hline $3,84 \mathrm{v}$ & Utara & $2,98 \mathrm{v}$ & 0 \\
\hline $1,98 \mathrm{v}$ & Utara Utara Timur & $0,25 \mathrm{v}$ & 0 \\
\hline $2,25 \mathrm{v}$ & Timur Laut & $0,41 \mathrm{v}$ & 0 \\
\hline $0,41 \mathrm{v}$ & Timur Utara Timur & 0 \\
\hline $0,45 \mathrm{v}$ & Timur & $0,32 \mathrm{v}$ & 0 \\
\hline $0,32 \mathrm{v}$ & Timur Tenggara & $0,90 \mathrm{v}$ & 0 \\
\hline $0,90 \mathrm{v}$ & Tenggara & $0,62 \mathrm{v}$ & 0 \\
\hline $0,62 \mathrm{v}$ & Selatan Tenggara & $1,40 \mathrm{v}$ & 0 \\
\hline $1,40 \mathrm{v}$ & Selatan & $1,19 \mathrm{v}$ & 0 \\
\hline $1,19 \mathrm{v}$ & Selatan Barat Daya & $3,08 \mathrm{v}$ & 0 \\
\hline $3,08 \mathrm{v}$ & Barat Daya & $2,93 \mathrm{v}$ & 0 \\
\hline $2,93 \mathrm{v}$ & Barat Daya Barat & $4,62 \mathrm{v}$ & 0 \\
\hline $4,62 \mathrm{v}$ & Barat & $4,04 \mathrm{v}$ & 0 \\
\hline $4,04 \mathrm{v}$ & Barat Barat Laut & $4,78 \mathrm{v}$ & 0 \\
\hline $4,78 \mathrm{v}$ & Barat Laut & $3,43 \mathrm{v}$ & 0 \\
\hline $3,43 \mathrm{v}$ & Utara Barat Laut & 0 \\
\hline \multicolumn{3}{|c|}{ Rata-rata } \\
\hline
\end{tabular}

\section{Sensor Rain Gauge}

Rain Gauge adalah sensor curah hujan sama halnya seperti cara kerja limit switch. Pada saat air hujan mengisi dan memenuhi corong jungkat-jungkit dan air akan tumpah setelah corong terisi penuh. Tumpahan air akan mengakibatkan kontaktor switch akan terlepas sesaat normali open dan kembali tertutup setelah magnet manjauhi magnetik switch. Keadaan NC yang terjadi itu dimanfaatkan untuk memberikan informasi pada program arduino sebagai aktif LOW. Setiap kali magnetik switch terlepas, maka akan men-counter $1 \mathrm{x}$ (satu kali) kontak / 1 pulsa. 1 kali kontak / 1 pulsa sama dengan 0.011 inch $(0.2794 \mathrm{~mm})$ air hujan.

Tabel 8. Hasil sensor curah hujan

\begin{tabular}{|c|c|c|c|c|}
\hline $\begin{array}{c}\text { Curah } \\
\text { Hujan } \\
(\mathrm{mm})\end{array}$ & $\begin{array}{c}\text { Sensor } \\
\text { Curah } \\
\text { Hujan } \\
\text { (inc) }\end{array}$ & $\begin{array}{c}\text { Konversi } \\
\text { Curah } \\
\text { Hujan } \\
(\mathrm{mm})\end{array}$ & Error & $\begin{array}{c}\% \\
\text { Error }\end{array}$ \\
\hline 25,3 & 0,85 & 23,7 & $-1,6$ & 6,32 \\
\hline
\end{tabular}

\subsection{Pengaruh Salah Satu Router Off}

Tabel 9 menunjukkan saat router 2 dimatikan (off) setiap 1 menit, komunikasi tetap berjalan, tanpa terjadi terputusnya komunikasi maupun penundaan pengiriman informasi. Kondisi ini terjadi karena pada awal percobaan jaringan telah terhubung dengan router 1, sehingga, baik router 2 hidup ataupun mati, tidak akan berpengaruh terhadap komunikasi melalui router 1 .
Tabel 9. Pengaruh Router 2 On/Off

\begin{tabular}{|c|c|c|c|c|}
\hline \multirow{2}{*}{ No } & \multicolumn{2}{|c|}{ Router } & \multicolumn{2}{c|}{ End Device } \\
\cline { 2 - 5 } & R2 & $\begin{array}{c}\text { Time } \\
\text { hh:mm }\end{array}$ & $\begin{array}{c}\text { Komunikasi } \\
\text { on }\end{array}$ & $\begin{array}{c}\text { Komunikasi } \\
\text { off }\end{array}$ \\
\hline 1 & off 1 & $10: 24$ & $\sqrt{ }$ & \\
\hline 2 & off 2 & $10: 25$ & $\sqrt{ }$ & \\
\hline 3 & off 3 & $10: 26$ & $\sqrt{ }$ & \\
\hline 4 & off 4 & $10: 27$ & $\sqrt{ }$ & \\
\hline 5 & off 5 & $10: 28$ & $\sqrt{ }$ & \\
\hline
\end{tabular}

Tabel 9 menunjukkan saat router 2 dimatikan (off) setiap 1 menit, komunikasi tetap berjalan, tanpa terjadi terputusnya komunikasi maupun penundaan pengiriman informasi. Kondisi ini terjadi karena pada awal percobaan jaringan telah terhubung dengan router 1, sehingga, baik router 2 hidup ataupun mati, tidak akan berpengaruh terhadap komunikasi melalui router 1 .

Tabel 10. Pengujian Pengaruh Router On/Off

\begin{tabular}{|c|c|c|c|c|c|}
\hline \multirow{2}{*}{ No } & \multicolumn{2}{|c|}{ Router } & \multicolumn{2}{c|}{ Komunikasi } & Time \\
\cline { 2 - 5 } & R1 & R2 & On & Off & hh:mm:ss \\
\hline 1 & Off & On & & $\sqrt{ }$ & $10: 01: 00$ \\
\hline 2 & Off & On & $\sqrt{ }$ & & $10: 01: 11$ \\
\hline 3 & On & On & $\sqrt{ }$ & & $10: 01: 12$ \\
\hline 4 & Off & On & $\sqrt{ }$ & & $10: 02: 00$ \\
\hline 3 & On & Off & & $\sqrt{ }$ & $10: 02: 01$ \\
\hline 4 & On & Off & $\sqrt{ }$ & & $10: 02: 10$ \\
\hline 5 & On & On & $\sqrt{ }$ & & $10: 02: 11$ \\
\hline
\end{tabular}

Dari Tabel 10 dapat disimpulkan bahwa proses self healling jaringan dapat bekerja dengan baik dan lamanya waktu yang dibutuhkan oleh End Device untuk melakukan pembuatan jaringan komunikasi baru dapat dilihat saat komunikasi dari off ke on, saat pengujian no 1 ke no 2 terlihat selisih waktu dari 10:01:00 sampai 10:01:11 adalah 10s, kemudian terjadi off ke on lagi pada pengujian no 3 dan no 4 memiliki selisih waktu 9s, jadi rata-rata rataratanya dari kejadian itu 9,5s untuk bisa komunikasi on.

\subsection{Pengujian Delay Network Recovery dengan Variasi Jarak \\ Dari Tabel 11 dapat dilihat bahwa waktu} network recovery yang didapat mengalami kenaikan mengikuti kenaikan nilai jarak antar device. Berdasarkan hasil pengukuran dengan menggunakan stopwatch, didapatkan bahwa 
untuk jarak 250 meter sampai dengan 375 meter, waktu yang dibutuhkan untuk proses recovery network memiliki nilai minimum 11 detik dan delay maksimum sebesar 85 detik. Akan tetapi untuk jarak 250m dari End Device ke Router dan $400 \mathrm{~m}$ dari router ke Coordinator komunikasi terputus dikarenakan jarak maximal yang diuji adalah $375 \mathrm{~m}$.

Tabel 11. DNR dengan Variasi Jarak

\begin{tabular}{|c|c|c|c|c|c|c|c|}
\hline \multirow{2}{*}{ No } & \multirow{2}{*}{$\begin{array}{c}\text { Tx- } \\
\text { R(m) }\end{array}$} & \multirow{2}{*}{$\begin{array}{c}\text { R-Rx } \\
\text { (m) }\end{array}$} & \multicolumn{3}{|c|}{ Informasi } & \multirow{2}{*}{$\begin{array}{l}\text { Waktu } \\
\text { I (s) }\end{array}$} & \multirow{2}{*}{$\begin{array}{l}\text { Waktu } \\
\text { II (s) }\end{array}$} \\
\hline & & & Tx & $\mathrm{R}$ & $\mathrm{Rx}$ & & \\
\hline 1 & 250 & 25 & $\sqrt{ }$ & $\sqrt{ }$ & $\sqrt{ }$ & 11 & 12 \\
\hline 2 & 250 & 300 & $\sqrt{ }$ & $\sqrt{ }$ & $\sqrt{ }$ & 11 & 12 \\
\hline
\end{tabular}

\subsection{Pengelompokan Data dengan Fuzzy Clustering Mean (FCM).}

Data yang digunakan pada penelitian ini berasal dari stasiun Meteorologi Tabing Padang yang diukur perhari selama satu tahun yaitu data pada bulan Januari 2012 hingga Desember 2012. Data yang dimaksud adalah data empat variabel cuaca yang telah disebutkan pada bab sebelumnya yaitu suhu, kecepatan angin, kelembaban udara, dan curah hujan. Data masukan yang digunakan adalah variable suhu, kelembaban untuk mendapatkan variabel pengelompokan untuk menghasilkan pohon keputusan (decision tree) menggunakan algoritma C4.5. Untuk mengelompokan dengan Fuzzy Clustering Mean (FCM) dibutuhkan aplikasi MATLAB.
Tabel 12. Fungsi Keanggotaan Variabel Suhu

\begin{tabular}{|c|c|c|c|c|}
\hline No & $\begin{array}{c}\text { Nama } \\
\text { Input }\end{array}$ & Keterangan & $\begin{array}{c}\text { Standar } \\
\text { Deviasi }\end{array}$ & $\begin{array}{c}\text { Nilai } \\
\text { Rata- } \\
\text { rata }\end{array}$ \\
\hline 1 & suhu_lo & $\begin{array}{c}\text { Suhu } \\
\text { Rendah }\end{array}$ & 0,8012 & 25,48 \\
\hline 2 & suhu_av & $\begin{array}{c}\text { Suhu } \\
\text { Sedang }\end{array}$ & 0,8012 & 26,49 \\
\hline 3 & suhu_hi & Suhu Tinggi & 0,8012 & 27,41 \\
\hline
\end{tabular}

Tabel 13. Fungsi Keanggotaan Variabel Kelembaban

\begin{tabular}{|c|c|c|c|c|}
\hline No & $\begin{array}{c}\text { Nama } \\
\text { Input }\end{array}$ & Keterangan & $\begin{array}{c}\text { Standar } \\
\text { Deviasi }\end{array}$ & $\begin{array}{c}\text { Nilai Rata- } \\
\text { rata }\end{array}$ \\
\hline 1 & rh_lo & RHRendah & 4,7928 & 78,74 \\
\hline 2 & rh_av & RH Sedang & 4,7928 & 84,09 \\
\hline 3 & rh_hi & RH Tinggi & 4,7928 & 90,53 \\
\hline
\end{tabular}

\subsection{Data Mining Menggunakan Algoritma C4.5}

Dalam pembuatan data mining kita harus mempunyai data historis, data dari 1 tahun pada tahun 2012 yang berasal dari BMKG tabing padang, karena pada tahun 2012 ada beberapa kejadian banjir dan galodo di Batu Busuk. Kemudian data tersebut dianalisis; dataset tersebut memiliki 364 kasus yang terdiri 12 "Ya" dan 352 "Tidak" pada kolom Main.

Dari hasil algoritma C4.5 menghasilkan pohon keputusan, dari pohon keputusan akan dibuat rule prediksi banjir dengan menggunakan logika IF atau percabangan. Adapun hasil dari pohon keputusan akhir terdatapat 4 rule untuk prediksi akan potensi banjir sebagai berikut:

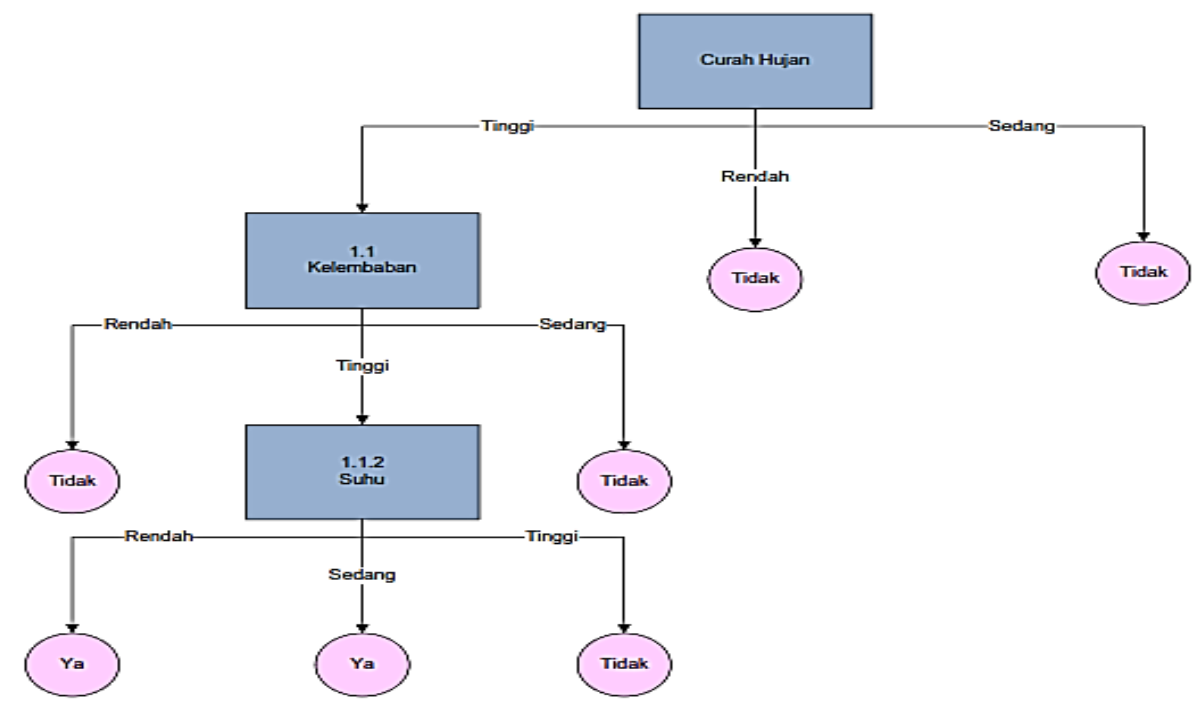

Gambar 6. Pohon Keputusan 
1. if(curah hujan is lo) or (curah hujan is av) then tidak berpotensi banjir

2. if( curah hujan is hi) and (kelembaban is lo) or (kelembaban is av) then tidak berpotensi banjir

3. if(curah hujan is hi) and (kelembaban is hi) and (suhu is hi) then tidak berpotensi banjir

4. if(curah hujan is hi) and (kelembaban is hi) and (suhu is lo) or (suhu is av) then berpotensi banjir

Dapat disimpulkan bahwa banjir akan terjadi jika curah hujan tinggi diikuti oleh kelembaban yang tinggih serta suhu rendah atau sedang.

\subsection{Pengukuran Delay Ke server}

Untuk mengukur delay dari coordinator ke komputer server maka dibutukan rangkaian Real Time Clock (RTC), sehingga dapat membandingkan waktu pengiriman data dari Batu Busuk dengan waktu diserver, dengan hasil pengujian terdapat pada Tabel 14:

Tabel 14. Pengujian waktu pengirim ke server

\begin{tabular}{|c|c|c|c|}
\hline No & $\begin{array}{c}\text { RTC } \\
\text { hh:mm:ss }\end{array}$ & $\begin{array}{c}\text { Server } \\
\text { hh:mm:ss }\end{array}$ & $\begin{array}{c}\text { Delay } \\
\text { S }\end{array}$ \\
\hline 1 & $6: 24: 35$ & $6: 25: 41$ & 66 \\
\hline 2 & $6: 24: 42$ & $6: 25: 46$ & 64 \\
\hline 3 & $6: 24: 45$ & $6: 25: 49$ & 64 \\
\hline 4 & $6: 24: 44$ & $6: 25: 47$ & 63 \\
\hline 5 & $6: 24: 47$ & $6: 25: 50$ & 63 \\
\hline 6 & $6: 24: 49$ & $6: 25: 52$ & 63 \\
\hline 7 & $6: 24: 51$ & $6: 25: 54$ & 63 \\
\hline 8 & $6: 24: 53$ & $6: 25: 56$ & 63 \\
\hline 9 & $6: 24: 55$ & $6: 25: 58$ & 63 \\
\hline 10 & $6: 24: 57$ & $6: 26: 00$ & 63 \\
\hline 11 & $6: 24: 59$ & $6: 26: 02$ & 63 \\
\hline 12 & $6: 25: 01$ & $6: 26: 19$ & 78 \\
\hline 13 & $6: 25: 17$ & $6: 26: 20$ & 63 \\
\hline 14 & $6: 25: 18$ & $6: 26: 21$ & 63 \\
\hline 15 & $6: 25: 20$ & $6: 26: 24$ & 64 \\
\hline 16 & $6: 25: 22$ & $6: 26: 25$ & 63 \\
\hline 17 & $6: 25: 23$ & $6: 26: 27$ & 64 \\
\hline 18 & $6: 25: 25$ & $6: 26: 29$ & 64 \\
\hline 19 & $6: 25: 27$ & $6: 26: 30$ & 63 \\
\hline 20 & $6: 25: 29$ & $6: 26: 33$ & 64 \\
\hline \multicolumn{3}{|c|}{ Rata-rata Delay } & 64,2 \\
\hline
\end{tabular}

Berdasarkan pengujian yang dilakukan, terhadap waktu pengiriman informasi dari titik coordinator yang berada di Batu Busuk menuju server maka rata-rata waktu yang dibutuhkan adalah 64,2 second atau 1 menit 4 second.

\subsection{Pengujian Perangkat Lunak}

Dalam pengujian sistem informasi EWS ke Raspberry $\mathrm{Pi}$ sebagai komputer server, digunakan software Mozilla sebagai web browser dengan url http://ews.polinpdg.ac.id . Hasil eksekusi program aplikasi EWS adalah Monitoring dan Prediksi banjir dimana memberikan informasi kapan waktu sistem terakhir diperbaharui dari nilai curah hujan, suhu, kelembaban relatif dan kecepatan serta arah angin, keputusan prediksi banjir. Gambar 7 merupakan tampilan interface aplikasi monitoring dan prediksi banjir pada EWS yang ditampilkan.

Secara umum sistem informasi EWS ditampilkan dalam bentuk web page yang ditampilkan secara realtime dimana disesuiakan dengan keadaan sekarang dan grafik sendiri menampilkan nilai suhu, memiliki 10 kolom jarak diantaranya 1 menit, ini dapat dilihat pada gambar diatas misalkan satu menit sebelum 15:05 adalah 15:04 begitu seterusnya. Untuk keadaan realtime cuaca berdasarkan curah hujan contohnya seperti gambar tidak hujan disesuikan dengan curah hujan 1 jam yang lalu, yang mana kriterianya disesuiakan dengan data BMKG. Untuk early warning system sendiri didapat dari data mining mengunakan metoda algoritma C4.5 yang menghasilkan pohon keputusan apakah berpotensi banjir atau tidak berpotensi banjir.

Pengujian dilakukan beberapa percobaan yang dapat dilihat secara realtime, hasil uji dapat diakses http://ews.polinpdg.ac.id, website akan merefresh web page secara otomatis dengan waktu $1188 \mathrm{~ms}$, ini terlihat pada GET http://ews.polindg.ac.id/site/home, untuk lebih detailnya dapat dilihat Gambar 8.

\subsection{Pengujian EWS untuk Memprediksi banjir \\ Pengujian dilakukan selama empat hari} berurut-turut, dimulai pada tanggal 18/03/2016 sampai tanggal 22/03/2016.

Ada beberapa tahapan dalam memprediksi banjir yaitu:

1. Menentukan kategori hujan, dari data hujan perhari.

2. Selanjutnya tentukan juga kategori kelembaban dan suhu berdasarkan hasil FCM.

3. Terakhir setelah kedua langkah dilakukan baru bisa mengimplikasikan dalam EWS dengan menggunakan pohon keputusan, dengan algoritma C.45 


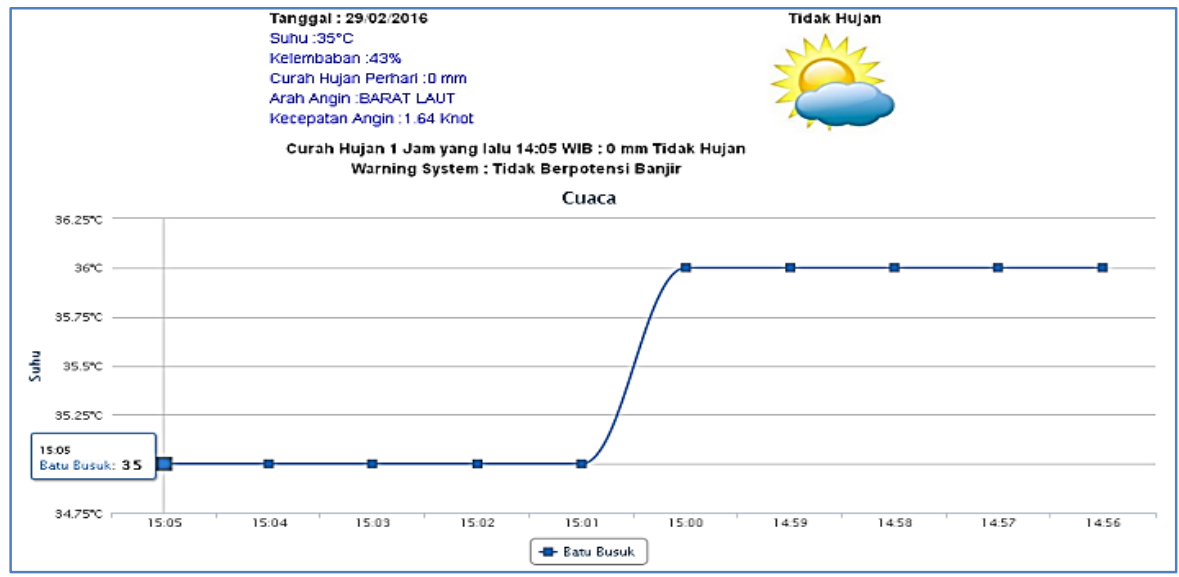

Gambar 7. Sistem Informasi EWS

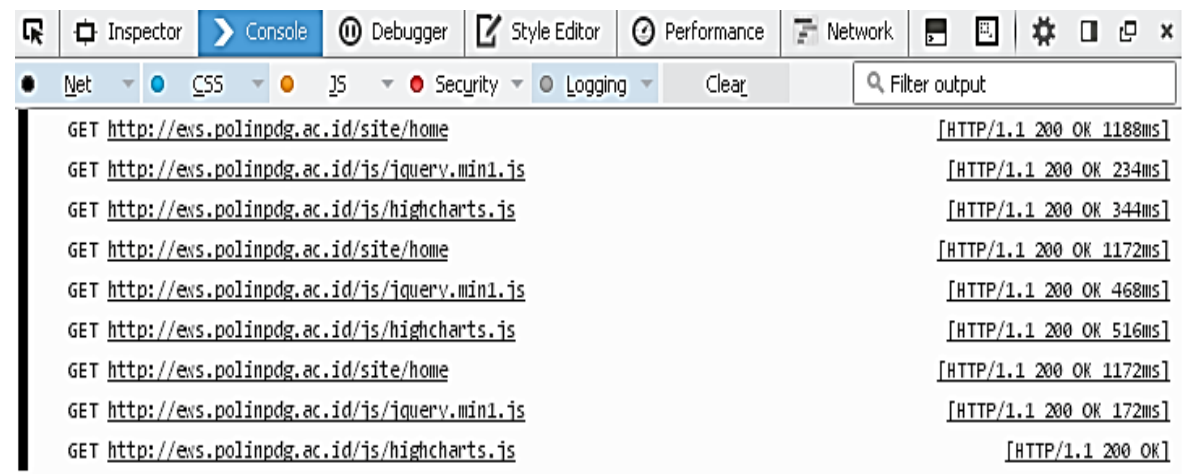

Gambar 8. Delay Refreh Web Page EWS

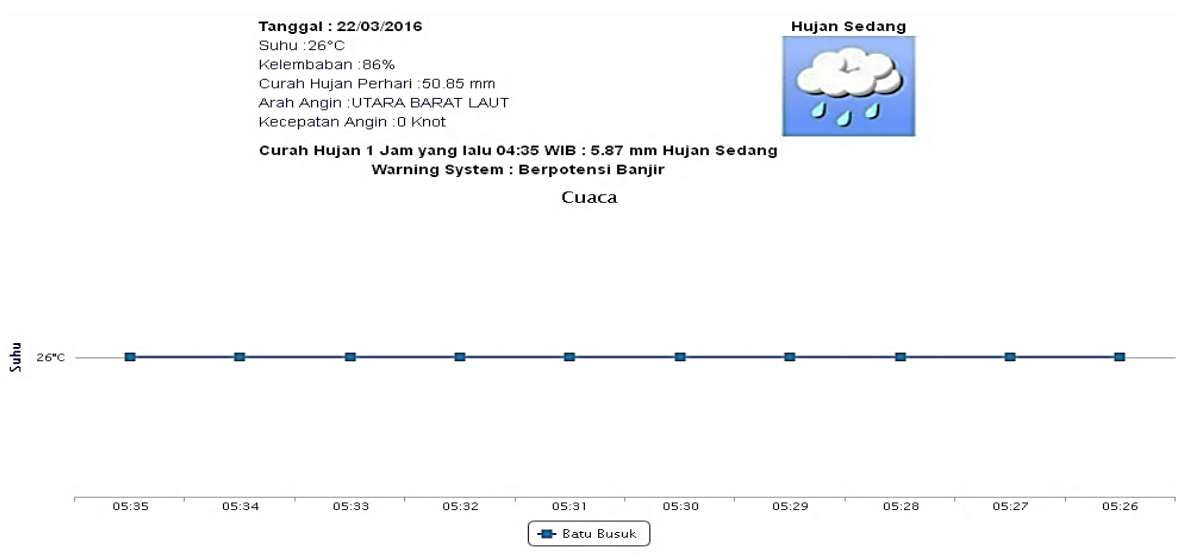

Gambar 9. Informasi Potensi Banjir di Web

Tabel 15 Hasil Pengujian EWS

\begin{tabular}{|c|c|c|c|c|c|c|c|}
\hline Tanggal & Mulai & Akhir & $\begin{array}{c}\text { Total } \\
\text { Record }\end{array}$ & $\begin{array}{c}\text { Curah } \\
\text { Hujan }\end{array}$ & Kelembaban & Suhu & EWS \\
\hline 18/03/2016 & $9: 41: 55$ & $23: 52: 59$ & 22451 & Hujan Av & Rh Av & Suhu Av & Tidak berpotensi Banjir \\
\hline 19/03/2016 & $13: 48: 33$ & $23: 53: 01$ & 18363 & Hujan Lo & Rh Lo & Suhu Av & Tidak berpotensi Banjir \\
\hline 21/03/2016 & $08: 44: 59$ & $23: 53: 00$ & 20995 & Hujan Av & Rh Av & Suhu Av & Tidak berpotensi Banjir \\
\hline 22/03/2016 & $0: 00: 02$ & $07: 55: 38$ & 8222 & Hujan Hi & Rh Hi & Suhu Av & Berpotensi Banjir \\
\hline
\end{tabular}


Pada tanggal 22/03/2016 kota padang dilanda banjir di akibatkan hujan yang menguyur kota padang mulai tanggal 21/03/2016 pada senja hari sampai subuh hari tanggal 22/03/2016. EWS mengeluarkan informasi potensi banjir pada pukul 5:45:57, EWS dapat berkerja dengan baik karena informasi memiliki kesamaan dengan kondisi real yang ada di padang umumnya dan aliran Batu Busuk khususnya.

\section{Kesimpulan}

Berdasarkan pada hasil perancangan, pengujian dan analisa yang dilakukan terhadap Early Warning System (EWS) yang dibangun, maka didapatkan beberapa kesimpulan sebagai berikut :

1. Hasil pengujian pengukuran sensor menunjukkan bahwa suhu yang terukur oleh SHT11 mempunyai kesalahan rata-rata pada suhu 2,09\%, kelembaban relative 0,59\%, kecepatan angin $3,87 \%$ dan arah angin $0 \%$ serta curah hujan $6,32 \%$ dari pengukuran alat ukur sebenarnya.

2. Rata-rata waktu network recovery yang dibutuhkan oleh perangkat untuk membangun jaringan komunikasi baru setelah jaringan terputus akibar router mati adalah 10,9 detik dengan kondisi jarak tetap dengan jarak $250 \mathrm{~m} \mathrm{~s} / \mathrm{d} 250 \mathrm{~m}$.

3. Pengaruh jarak terhadap waktu penerimaan data adalah berbanding lurus. Semakin jauh jarak antara transmitter, router dan receiver, maka semakin lama waktu penerimaan data, jarak maximal yang diuji adalah $250 \mathrm{~m}$ dan $375 \mathrm{~m}$ dengan delay $85 \mathrm{~s}$.

4. Penggunaan data mining dengan metoda Algoritma C4.5 dari variable cuaca yaitu curah hujan, kelembaban dan suhu. Menjelaskan bahwa root tertinggi akibat banjir untuk variable cuaca adalah curah hujan diikuti oleh kelembaban dan suhu.

5. Pengujian delay pengiriman data dari Batu Busuk ke server raspberry pi adalah 64,2 s, artinya data yang ditampilkan raspberry pi adalah data 64,2 s yang lalu dari Batu Busuk.

6. Pengujian EWS pada hari pertama, kedua jika dibandingkan dengan kondisi real Batu Busuk memiliki keadaan yang sama dengan EWS. Pada hari keempat mulai terjadi hujan dari sore sampai malam hari, serta dilanjutkan dihari kelima dari dini hari sampai subuh dengan curah hujan yang tinggi, dengan kondisi itu jika dibandingkan dengan hasil pohon keputusan dengan algoritma C4.5 EWS mengeluarkan peringatan akan potensi banjir yang di informasikan pada tanggal 22/03/2016 pukul 05:35:00 WIB, dimana kondisi itu kota padang dilanda banjir. EWS akan bekerja dengan baik jika tidak terjadi kondisi mati lampu atau dimatikan.

\section{DAFTAR PUSTAKA}

[1] Fithriah Musadat, Zahir Zainuddin, Merna Baharuddin, "Implementasi Algoritma Untuk Prediksi Curah Hujan Pada Sistem Pendeteksian Dini Bencana Banjir", 2013.

[2] Nor Azlina Ab. Aziz, Nor Azlina Ab. Aziz,"Managing Disaster with Wireless Sensor Networks", ICACT2011, Februari. 2011

[3] Irwan Dinata, Wahri Sumanda, "IMPLEMENTASI WIRELESS MONITORING ENERGI LISTRIK BERBASIS WEB DATABASE" Jnte Fakultas Teknik Unand Vol: 4, No. 1, Maret 2015. Maret 2013

[4] Sun Jun Lee, Keng Siau, "A review of datamining techniques", Industrial Manajement and Data System, Januari. 2001.

[5] Gaurav L. Agrawal, Prof. Hitesh Gupta, "Optimization of C4.5 Decision Tree Algorithm for Data Mining Application", ISSN 2250-2459 Volume 3,Issue 3, March.2013.

[6] Rahmad Dawood, Said Fairuz Qiana, Sayed Muchallil, "Kelayakan Raspberry Pi sebagai Web Server", Jurnal Rekayasa Elektrika Vol. 11 No. 1, April 2014.

[7] Suman Saha, Mitsuji Matsumoto, "A Framework for Disaster Management System and WSN Protocol for Rescue Operation",IEE 2007, Maret .2007.

[8] Cholatip Yawut, Sathapath Kilaso "A Wireless Sensor Network for Weather and Disaster Alarm Systems ", IPCSIT vol.6 (2011), Juni. 2011.

[9] Fadhli Palaha, Zaini, "PROPAGASI INDOOR GELOMBANG RADIO PERANGKAT XBEE DI RUMAH SAKIT IBU DAN ANAK BUDHI MULIA PEKANBARU” Jnte Fakultas 
Teknik Unand Vol: 3 No. 2 September 2014. September 2014

[10] Nur Endah Sari, Dr. Edi Sukirman, S.Si., MM., "Prediksi Cuaca Berbasis Logika Fuzzy Untuk Rekomendasi Penerbangan Di Bandar Udara Raja Haji Fisabilillah" 2012.

[11] Maxim Vladimirovich Shcherbakov, dkk, "A Survey of Forecast Error Measures" Information Technologies in Modern Industry, Education \& Society. 2013

\section{Biodata Penulis}

Roni Putra,S.Kom, Menamatkan pendidikan S1 di STMIK Indonesia Jurusan Sistem Informasi dan saat ini sedang menempuh pendidikan S2 pada Jurusan Teknik Elektro Universitas Andalas. 